\title{
Norsk Arkeologisk Selskap
}

\section{Årsberetning og regnskap 2018}

Den ordinære generalforsamling for 2018 ble avholdt 22. mars $2018 \mathrm{i}$ «Professorboligen», Karl Johansgate 47 i Oslo. Til stede var det 63 medlemmer.

Følgende ble protokollert fra generalforsamlingen:

- Preses, Lyder Marstrander, ønsket velkommen til den 81. generalforsamling. Erik Schultz ble valgt til å undertegne protokollen.

- Årsberetningen og regnskapet var sendt ut sammen med innkallingen til generalforsamlingen.

- Lyder Marstrander gikk gjennom regnskapet for 2017. Det ble også informert om at Arkeologisk fond blir satt på vent i 2018, ettersom Selskapet ikke lenger er en del av innkjøpsordningen til Ceres. Generalsekretær Frode Iversen informerte om prosessen rundt søknaden om å bli med i innkjøpsordningen, og avslaget fra Ceres.

- Preses leste opp revisjonsrapporten, som ble vedtatt av generalforsamlingen.

\section{Medlemskontingenten}

Styret foreslo å øke kontingent for 2019 med 25 kroner:

Kr. 425,- for enkeltmedlemmer

Kr. 550,- for ektepar/familiemedlemskap

Kr. 250,- for studenter/skoleelever

Livsvarig medlemskap er 20 ganger kontingenten for enkeltmedlemmer.

Det kom forslag fra salen om at studentmedlemskapet ikke burde økes. Det kom også forslag om å øke familiemedlemskapet med mer enn 25 kroner. Styrets forslag ble vedtatt av generalforsamlingen, men med instruksjon om å øke kontingenten mer. 


\section{Valg}

Lyder Marstrander redegjorde for valgkomiteens forslag til styresammensetning for 2018:

Preses: $\quad$ Lyder Marstrander (ikke på valg)

Styremedlemmer: Elin Dalen (ikke på valg)

Christian Størmer (ikke på valg)

Sonja Robøle (gjenvalg 2018 og 2019)

Ronny Henriksen (gjenvalg 2018 og 2019)

Leif Dan Birkemoe (gjenvalg 2018 og 2019)

Per Kristian Skulberg (ikke på valg)

Ellen Drage (ikke på valg)

Generalsekretær: Frode Iversen (ikke på valg)

Revisor: $\quad$ Kaare Castberg (2018 og 2019)

Valgkomiteens forslag ble vedtatt.

Valgkomité for 2018: Egil Mikkelsen, Jorun Vandvik Johnsen og Susanna Thommessen (ikke på valg)

\section{Eventuelt}

Det var ikke kommet inn noen saker på dette punktet. Den formelle delen av generalforsamlingen ble derfor avsluttet.

\section{Foredrag}

Det ble videre holdt to foredrag:

Dr. Anders Romundset, forsker ved NGU: Strandforskyving i rykk og napp

Gaute Reitan, arkeolog KHM: Steinalderen fra A til Å på 23 kilometer

Etter foredragene ble det servert ost og vin til 60 deltagere.

\section{Turer}

Norsk Arkeologisk Selskap arrangerte vårtur til Sør England 10.-15. mai 2018. 90 personer deltok på turen. Fagansvarlig for programmet var generalsekretær Frode Iversen. Arrangementsansvarlig og turleder var styremedlem Sonja Robøle.

Lørdag 9. september gikk årets høsttur til Ringerike. Turdeltakerne fikk blant annet besøke Stein gård og Veien kulturminnepark, se helleristningene ved Sundvollen, og Norderhov kirke og Ringerikes museum. Det var til sammen 81 påmeldte. Fagansvarlig for programmet var generalsekretær Frode Iversen. Arrangementsansvarli g og turleder var styremedlem Sonja Robøle. 


\section{Foredrag}

Tirsdag 27. februar hadde NAS gleden av å presentere nye mastere i arkeologi. 30 personer dukket opp for å drikke et glass vin å høre på de tre foredragene.

Alexander Frivoll: Identifisering og klassifisering av littiske råmaterialer i sør- og østnorsk steinalderforskning - Reliabilitet av visuell klassifikasjonsmetode.

Ida-Desiree Steen: Rituelle deponeringer i middelalder Norge - En undersøkelse av blyamuletters kontekst og inskripsjon.

Eirin Susann Beenberg: Rituell topografi. En analyse av gullbrakteatdepoters topografiske plassering i Vest-Agder og Rogaland i folkevandringstid.

Torsdag 11. oktober inviterte NAS, i samarbeid med Vestfold historielag og Slottsfjellsmuseet, til foredrag på Slottsfjellsmuseet i Tønsberg. Om lag 70 personer kom for å høre arkeolog Lars Haugesten, prosjektleder hos NIKU, presentere resultatene fra de siste års arkeologiske undersøkelser i Tønsberg.

\section{Stiftelsesmiddagen}

Fredag 23. november 2018 ble den sjette stiftelsesmiddagen arrangert i Det Norske Videnskaps-Akademiets lokaler, Drammensveien 78 i Oslo.

Det ble holdt tre foredrag før middagen:

Generalsekretær Frode Iversen, professor i arkeologi, Kulturhistorisk museum i Oslo, informerte om Gjellestadfunnet.

Dr. Anne Lene Melheim, seksjonsleder ved arkeologisk seksjon Kulturhistorisk museum, UiO. Om skipsgraver og reisens betydning i nordisk bronsealder.

Dr. Zanette Glørstad, leder av vikingtidsforskergruppen (ViS) ved Kulturhistorisk museum, UiO. Båtgraver i vikingtid. Politikk og verdensbilde.

Etter foredragene ble det servert en toretters middag.

\section{Arkeologisk fond - tildelinger 2018}

Det ble ikke utlyst tildelinger fra fondet ettersom NAS ikke mottok noen støtte fra Ceres for årene 2018-2020. Fondsstyret har bestått av Lyder Marstrander, Frode Iversen, Egil Mikkelsen og Petter B. Molaug. Arkeologisk fond har 65050 kroner på konto.

\section{Økonomisk situasjon}

Selskapets økonomi er i god orden. Årsregnskapet er lagt frem under forutsetning av fortsatt drift. Årsregnskapet viser et underskudd på kr 69989 kroner for 2018. Dette kan forklares med et kursfall på 44597 kr i fondene fra Skagen Global og Holberg Norden. Videre har 
ikke tidsskriftet Viking kommet med i innkjøpsordningen til Ceres. Det har også vært en nedgang i antall medlemmer, og færre salg av Viking. Etter styrets mening gir det fremlagte regnskap et korrekt bilde av selskapets resultat og stilling. Selskapets regnskap føres av deltidsansatt sekretær.

Styret har møttes 5 ganger i løpet av året. På styremøtet 3. september 2018 vedtok styret, etter instruksjon fra generalforsamlingen, nye priser for kontingent fra 2019. Enkeltmedlemskap ble økt med 50 kroner, familiemedlemskap ble økt med 75 kroner og studentmedlemskap ble økt med 25 kroner.

Norsk Arkeologisk Selskap hadde i 2018 til sammen 459 medlemskap i Norge og i utlandet. Det er 89 institusjoner/tidsskriftformidlere som kjøpte inn Viking.

Det er registrert 21 innmeldinger og 47 utmeldinger. Det høye antallet utmeldinger, og nedgangen i antall medlemmer, skyldes også en opprydding i medlemslistene.

\section{Viking}

Viking 2018 ble trykket hos 07 Media AS i Oslo, og ble sendt til medlemmene i slutten av november.

Redaksjonen har i 2018 bestått av Herdis Hølleland (redaktør), Astrid Nyland, Kjetil Loftsgarden, Christian Rødsrud og Astrid Tvedte Kristoffersen (redaksjonssekretær). Sonja Vibeche Robøle og Priscilla Field har lest korrektur. 
Regnskap fra 1.1.2018 - til 31.12.2018

Balanse pr. 31.12.2018

\section{EIENDELER}

DnB NOR 7001.06.00365

509835

DnB NOR 7056.66.15191

582427

DnB NOR 5084.05.24075

407

Skagen Global

309320

Holberg Norden

221991

Forskuddsbetalte kostnader

15129

Lønnsforskudd

$-2073$

Kundefordring

10685

Sum eiendeler

\section{GJELD OG EGENKAPITAL}

Skyldig AGA ferielønn

2624

Skyldige feriepenger

18473

Skyldige lønn

2614

Arkeologisk Fond 2018:

Pr.1.5.18

65297

- utbetalt i 2018

+ renter 2018

245

65051

\section{Kapitalkonto:}

Pr. 31.12.18

1286336

Overskudd

69989

Sum gjeld og egenkapital

1647765 


\section{Resultatregnskap 2018}

\section{Inntekter:}

Medlemskontingent

170071

Salg av Viking

80188

Inntekter arrangementer

1288805

Renteinntekter

2475

Sum inntekter

1541540

\section{Utgifter:}

Lønninger

194761

Feriepenger

18473

Arbeidsgiveravgift

21451

Arbeidsgiveravgift påløpne feriepenger

2605

Kostnadsgodtgjørelse

4792

Utgifter arrangement

1165881

Webhuset (hjemmeside/epost)

4198

Datautstyr/Visma

3393

Trykking/utsendelse Viking

Diverse utgifter Vikingredaksjonen

107038

4168

Møter/kurs/husleie/inventar

8264

Kontorrekvisita,porto, telefon

19453

Kursnedgang Holberg Norden

34772

Kursnedgang Skagen Global

9826

Kjøp annonse

5600

Yrkesskadeforsikring

Bankomkostninger

6429

Sum utgifter

1611529

Årets underskudd/overskudd

$-69989$ 


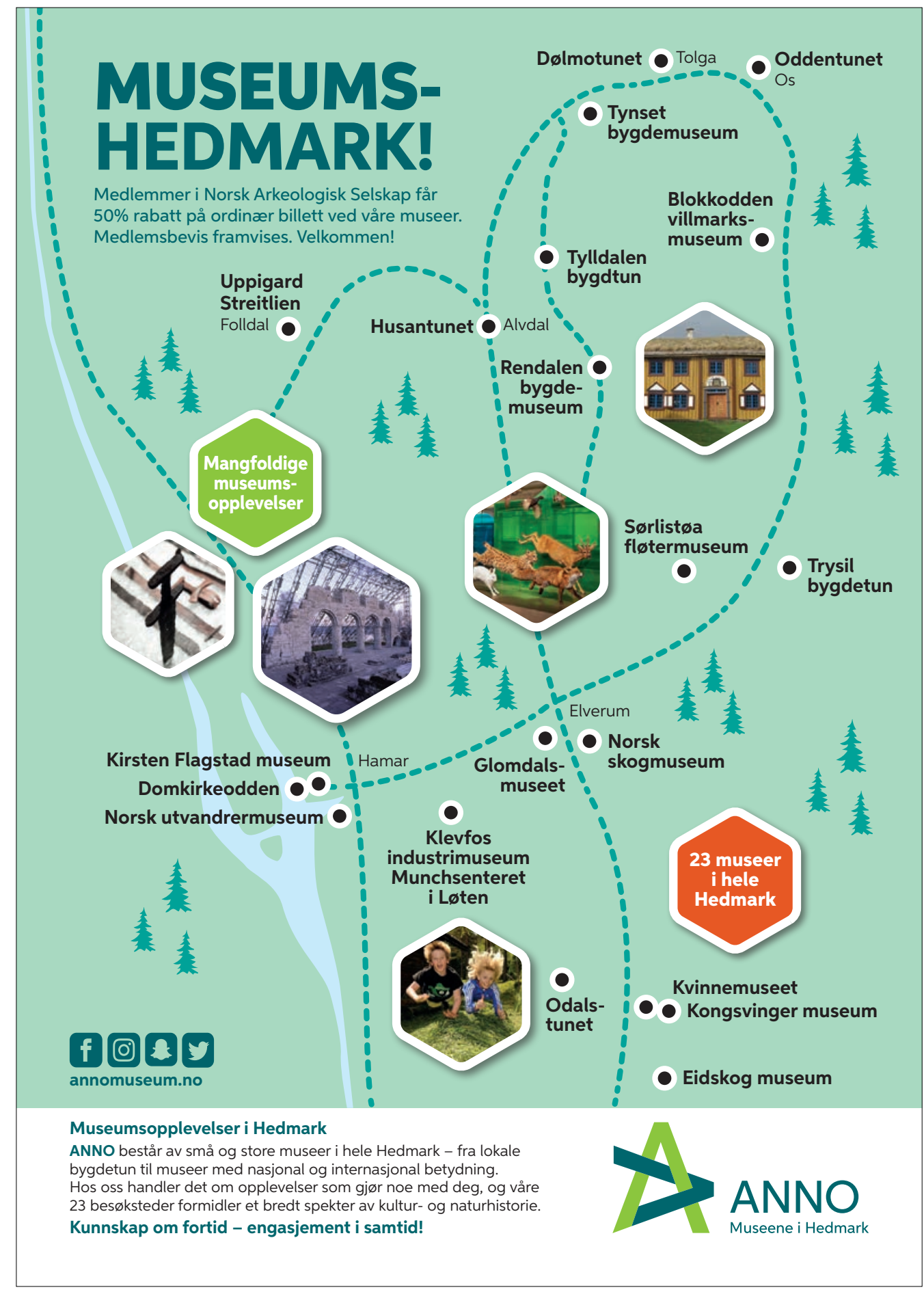




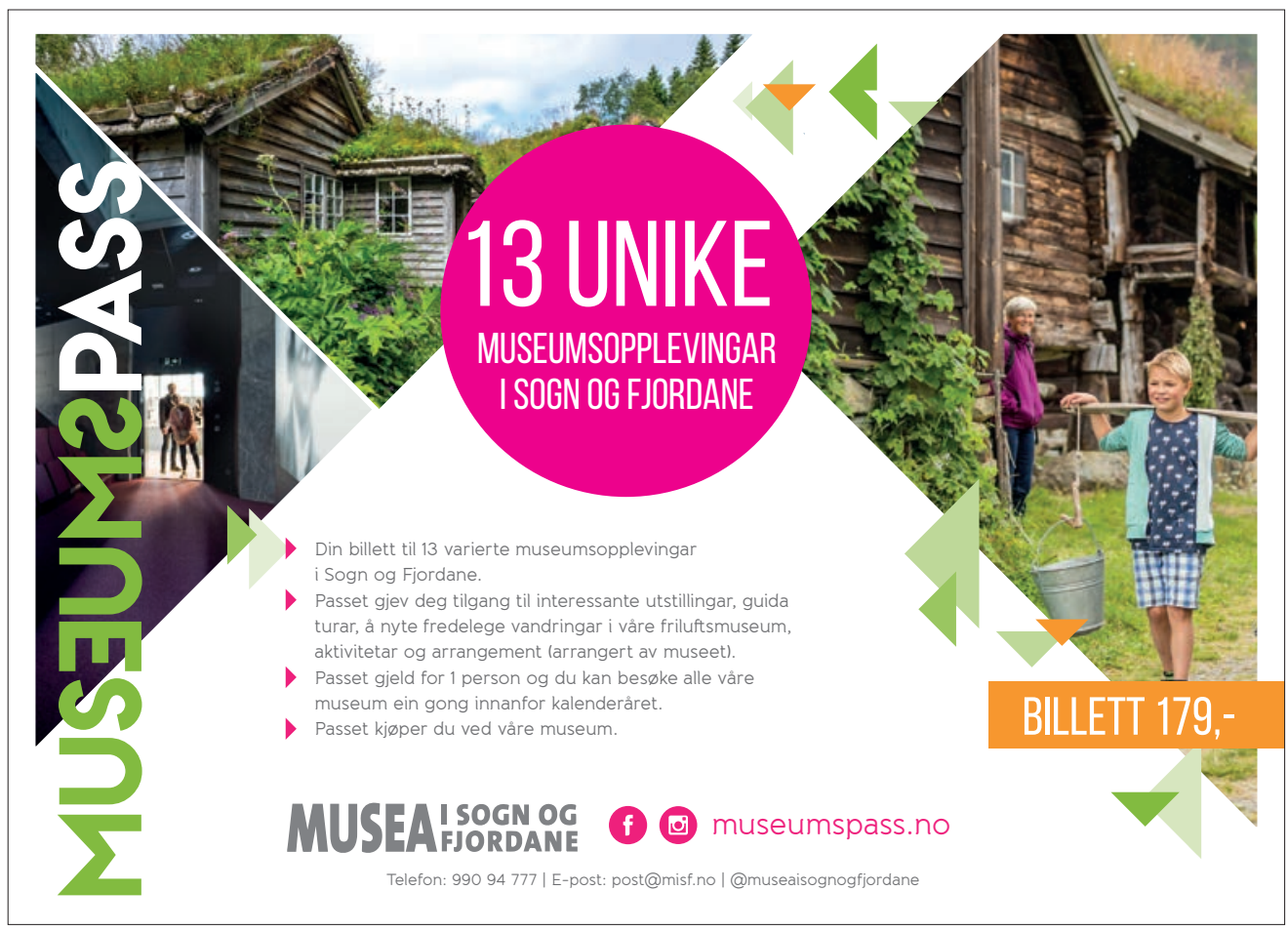

